\title{
From Fancy Amoeba to Fallible Self
}

Peirce's Evolutionary Theory of Human Persons

\section{Robert Main}

\section{OpenEdition}

\section{Journals}

Electronic version

URL: http://journals.openedition.org/ejpap/933

DOI: $10.4000 /$ ejpap.933

ISSN: 2036-4091

Publisher

Associazione Pragma

\section{Electronic reference}

Robert Main, «From Fancy Amoeba to Fallible Self», European Journal of Pragmatism and American Philosophy [Online], II-1 | 2010, Online since 01 July 2010, connection on 22 April 2019. URL : http:// journals.openedition.org/ejpap/933 ; DOI : 10.4000/ejpap.933

This text was automatically generated on 22 April 2019

\section{(c)}

Author retains copyright and grants the European Journal of Pragmatism and American Philosophy right of first publication with the work simultaneously licensed under a Creative Commons AttributionNonCommercial-NoDerivatives 4.0 International License. 


\title{
From Fancy Amoeba to Fallible Self
}

\author{
Peirce's Evolutionary Theory of Human Persons
}

Robert Main

\section{Introduction}

1 A perennial concern among Peirce commentators has been the articulation of Peirce's model of individual selfhood which underwrites his notion of self-control. A sticking point for most accounts is that Peirce seems to characterize the self along two different lines, at times describing it as a sign and produced by a community while at others characterizing it primarily in terms of embodiment and continuity with the rest of nature. However, if we adopt a view of Peirce's evolutionary metaphysics along the lines of what I call his "Darwinianized Hegelism," then Peirce's speaking about the self in these apparently contrasting ways is precisely what we would expect. In this paper, I draw on one of Peirce's unpublished manuscripts (MS 329) to trace the development of his theory of the self in terms afforded by both aspects of his metaphysics (the Darwinian and the Hegelian), beginning with the biological origins of consciousness (the condition for selfhood on the level of the species), and then proceeding to his semiotic account of the cultural and linguistic formation of cognition and "personality" (Peirce's favored term for those aspects of selfhood which are not reducible to biology alone). In doing this, I show that fallibilism is a crucial element in both lines of development and reemerges as part of the organizing principle of the joint workings of both processes. The final account hints at a promising connection between Peirce and Josiah Royce on this theme (an idea which I introduce, but do not pursue in this paper).

\section{Piecing Together Peircean Selfhood}

2 With regard to the individual self, Peirce is most known for a model which is cast largely in negative terms: "since his separate existence is manifested only by ignorance and error," Peirce says, the individual person, "so far as he is anything apart from his fellows, and from what he and they are to be, is only a negation" (W 2: 241-2). Peirce will hold to 
this characterization throughout his career, even in the mature philosophy which many take to exhibit a significant departure from his earlier views. In a letter to Josiah Royce, dated June 30,1913, Peirce says that

I came to the conclusion...that the only thing distinctive of volition is a peculiar consciousness of two-ness, distension [distention between a sharply-focused object that volition 'objects' to, though it can't intend to abolish since intention involves more than volition and a pushed-back back-ground that we call 'Myself'] between the sharply focussed [sic.] object and the pushed-back background Self; and I believe there is no other consciousness of the Self. (as cited in Oppenheim 1993: 241-2) ${ }^{1}$

3 In this later formulation, Peirce emphasizes the primacy of Secondness in the experience of our own selves; we are made aware of our selves by way of the resistance of reality. This is in keeping with Peirce's understanding of experience as teaching by way of surprise, and consisting of "forcible modification of our ways of thinking" by way of "the influence of the world of fact" (EP2: 370). Consequently, "all the actual character of consciousness is merely the sense of the shock of the non-ego upon us. Just as a calm sea sleeps except where its rollers dash upon the land" (CP 8.265-266). This is, of course, another way of saying that the individual self is characterized by its fallibility, that the beliefs which comprise its habits of (potential) action could be false and would then be met with resistance by reality. To say that this is the only "consciousness of the Self" is to say that we are only conscious of ourselves as fallible.

But does Peirce also provide a positive model of the self, one capable of meeting the objection raised by Richard Bernstein, that Peirce fails to provide a "coherent theory of the self which would make sense of the idea of 'self-control"' (Bernstein 1971: 197)? Moreover, does he provide a model that has anything to offer contemporary philosophical concerns such as naturalism? The answer to these questions, I believe, is both yes and no; Peirce does sketch the beginnings of such a model, one that takes the individual self to be a sign initially defined by its community. However, the outline is scattered and incomplete. A more satisfactory model requires extending this outline and might, I think, be found in the mature thought of Josiah Royce, which demonstrates a significant Peircean influence. Before turning to such an account, however, we would do well to look, first, at its foundation, the model of selfhood as it is presented in Peirce's own philosophy.

5 A perennial concern among Peirce commentators has been the articulation of Peirce's model of individual selfhood which underwrites his notion of self-control. A sticking point for most accounts is that Peirce seems to characterize the self along two different lines, at times describing it as a sign and with respect to a community while at others characterizing it primarily in terms of embodiment and continuity with the rest of nature. However, if we adopt a view of Peirce's evolutionary metaphysics along the lines of what I call his "Darwinianized Hegelism," then Peirce's speaking about the self in these apparently contrasting ways is precisely what we would expect. ${ }^{2}$ Given that his metaphysics draws on both a Darwinian-styled model of chance-driven biology and a Hegelian-like account of the evolution of reason and culture, it follows that the Peircean self would emerge out of an interaction of these two processes. In fact, this may be the most significant motivating principle of his cosmology, which, it has been noted, tends toward the anthropomorphic. That is, Peirce synthesizes Darwinian and Hegelian evolutions because each is, taken alone, insufficient for describing both the natural world (conceived in terms that are independent of human thought and culture) as well as 
human institutions, practices and meanings which are of central concern for human persons. By drawing on a line of thought that is isomorphic with Hegel's own (although, according to Peirce, developed independently of any Hegelian influence) Peirce is pointing to the inadequacies of the Darwinian model in accounting for culture and its artifacts, notably human selves; these cannot be reduced to mere biology or the operation of chance which Peirce takes to be the governing process in natural selection. However, in his frequent criticisms of Hegel's relation to science - a view he often con- trasts with that of Darwin - Peirce is showing that biological development and the world revealed by the natural sciences themselves cannot be reduced to the evolution of culture, Mind or Geist. To employ this reductive strategy would indeed be overly anthropomorphic, and would ignore both the persistence of external reality and the limitations of actual humans. ${ }^{3}$ It is only by viewing the self as the product of both operations working jointly that a full account of selfhood can be given. Perhaps because of this position, Peirce does not use the term "self" in anything like a technical sense. In fact, he often equivocates in his employment of that and related terms like "man." Consequently, the key to discovering Peirce's model of the self is to approach his account by way of the related concepts of consciousness, cognition, and personality, each of which Peirce does employ in a technical fashion.

6 I will proceed, then, by tracing the development of selfhood as Peirce understands it along the lines afforded by both aspects of his metaphysics, beginning with the biological origins of consciousness (the condition for selfhood on the level of the species), and then proceeding to his semiotic account of the cultural and linguistic formation of cognition and "personality" (Peirce's favored term for those aspects of selfhood which are not reducible to biology alone). In doing this, I show that fallibilism is the crucial element in both lines of development and reemerges as part of the organizing principle of the joint workings of both processes.

\section{The Evolution of Consciousness}

7 In Peirce's account, the selfhood of individuals depends upon a culturally-informed development of a species-wide level of consciousness. With respect to the biological origins of consciousness, one passage which is of particular note is found in Peirce's draft for a 1904 book review titled "Nichol's Cosmology and Pragmaticism." In the following selection from that paper, Peirce links the doctrines of fallibilism and synechism with the categories of Firstness, Secondness and Thirdness, (in both their phenomenological and metaphysical applications) in a myth-like account of the development of consciousness. As the majority of this manuscript has not been published, I will here quote the lengthy passage in full:

Questioner: The narrowness of your view of reality only appears more and more strikingly as you go on. You are, as you yourself well phrased it, simply color-blind to the idea of existence in itself.

Pragmaticist: Hylozoism, the doctrine that all matter feels, is an idle and senseless apology for a theory as long as there is no way of bringing it to the test of experiment; but as soon as such a way shall be found it will become a working hypothesis particularly well worth trying. Meantime, we have no difficulty in conceiving some being (call it by the name of amoeba, just to help the imagination) to have consciousness without the least trace of memory of any consciousness of change, of any self, of any action or any relation, - whether of difference, similarity, coexistence or of any sort whatsoever. It will have some quality of sentience, - say a 
solferino color, - which will not be an object to it, but a tinge of its life, unrecognized, of course, since it will have no power of recognition. You may say, if you chose to take that point of view, that in that solferino color the fancy-ameoba has an immediate knowledge of the entire universe of being, with this most goodly frame, the earth, and this majestical roof fretted with golden fire, and all. So considered, it is a knowledge absolutely flawless, without doubt, gap, or imperfection and of the very kind that Leibniz attributes to Deity. It has perfectly grasped the idea of pure being. Next, let us suppose that fancy-ameoba to undergo a metamorphosis (to give it a name, say into a fancy-worm) in consequence of which it is impelled from time to time to make conscious efforts, sometimes successful and sometimes not, to change its solferino to emerald green and back again or to resist spontaneous changes of this sort. It has a sense of the resistance. It feels the effort, a vague struggle for it knows not what; and this ceases upon success or, without success, by fatigue; but it has no ideal of its purpose, and no comparing power whatsoever. Though it has no sense of continuous time, it is aware of succeeding and of giving up. The poor creature is God no longer; its sense of actual happening has made it a finite being. You see what I am driving at: I am endeavoring to create the idea of a being that, unlike our fancy-ameoba, should virtually have the idea of existence or actuality, but without any trace of reason nor the idea of pragmatistic reality. I call your attention to the circumstance that the idea of sentiencial being which this fancy-ameoba virtually has (though of course it has no general idea) is necessarily possessed by the fancy-worm as well; though he has the virtual idea of existence and... (MS 329) ${ }^{4}$

Unfortunately, this portion of the manuscript ends here. We can, however, make a reasonable guess as to how it would continue, enabled by Peirce's remarks in other contexts; this will be attempted below. First, we must unpack Peirce's account of the initial stages of the evolution of consciousness in this context.

\section{The "Fancy Amoeba"}

After a brief remark about hylozoism, and an indication of how his own scientificallymodeled hypothesis differs from that doctrine in its traditional form, Peirce asks us to imagine an amoeba with certain characteristics, viz. a rudimentary form of protoconsciousness deprived of any awareness of self, time and relation. This particular amoeba, however, is given the curious qualification "fancy." The term "fancy" can be used to mean both the product of imaginative fantasy as well as to refer to animals which have been selectively bred so as to develop certain features. Peirce's use of the term here fits both definitions. That is, he is both offering a mythical sort of thought experiment meant to illustrate the evolution of consciousness but without any claims to its being a true account of such development, as well as speculatively "breeding" organisms that feature specific traits, viz. those that make up consciousness as we know it.

In his tale, Peirce connects doctrine of continuity with his triadic categories. The "fancy ameoba's" unrecognized, non-reflective "quality of sentience," it's "solferino color," is an example of Firstness. ${ }^{5}$ What is striking about this, however, is Peirce's comment "that in that solferino color the fancy-ameoba has an immediate knowledge of the entire universe of being, with this most goodly frame, the earth, and this majestical roof fretted with golden fire, and all." That is, through its color the amoeba has "absolutely flawless" knowledge of the universe that is entirely free from doubt. We can perhaps make more sense of this seemingly hyperbolic claim by looking to a passage from "The Law of Mind." In that paper, Peirce applies his categories to a phenomenology of ideas: "Three elements 
go to make up an idea. The first is its intrinsic quality as a feeling. The second is the energy with which it affects other ideas, an energy which is infinite in the here-andnowness of immediate sensation, finite and relative in the recency of the past. The third element is the tendency of an idea to bring along other ideas with it" (CP 6.135). These three elements of an idea are another application of Peirce's triadic system of categories, the first being an instance of Firstness akin to the amoeba's awareness of its solferino color. Later in "The Law of Mind," Peirce further articulates what he takes this first element to be: "The first character of a general idea so resulting is that it is living feeling. A continuum of this feeling, infinitesimal in duration, but still embracing innumerable parts, and also, though infinitesimal, entirely unlimited, is immediately present. And in its absence of boundedness a vague possibility of more than is present is directly felt" (CP 6.138). In light of this earlier account, we can conclude that the amoeba's "feeling" or experience of the First which is its color gives it "immediate knowledge of the entire universe of being" because such experience is not constrained by any limitation (internal or external); the full possibility of generalization with respect to that feeling is present to it. And, according to the "law of mind," this generalizability is itself unlimited, and in fact will continue to grow indefinitely (perhaps even infinitely). It is thus the counterpart in the evolution of consciousness of the absolute potentiality Peirce locates at the beginning of the evolution of the cosmos in A Guess at the Riddle (EP 1: 248).

\section{The "Fancy Worm"}

11 As Peirce continues his story and proceeds up the evolutionary ladder from "fancy amoeba" to "fancy worm," the primary distinction is the introduction of error, i.e., the failure of the fancy worm in some project that it is "impelled" to undertake (here the changing of its color) but which is not guided by conscious purpose. In this, the fancy worm has achieved the first requirement of consciousness, an awareness of the individual self as finite and fallible, and exhibits Peirce's category of Secondness: "The type of an idea of Secondness is the experience of effort, prescinded from the idea of a purpose [...] The experience of effort cannot exist without the experience of resistance. Effort is only effort by virtue of its being opposed" (CP 8.330). In effect, the fancy worm is not only made aware of its finitude, but actually becomes a finite being through its sensing of the resistance it encounters; according to Pierce, "its sense of actual happening has made it a finite being."

12 This raises the question, however, as to how this is indeed a move "up" in Peirce's evolutionary scale. That is, if the "fancy amoeba" possessed a divine sort of knowledge, how could the introduction of finitude and fallibility be viewed as progress? Peirce's answer in both the Guess manuscript and the related material found in MS 955 turns upon his distinguishing between reality and existence. For Peirce, evolution in its broadest form models the universe as moving from a point in the infinite past which is characterized as one of absolute potentiality to a point, in the infinite future, of absolute finality; this is the development from absolute Firstness to absolute Secondness (EP1: 251). In MS 955, Peirce reiterates a version of this account, showing it to be a consequence of the hypothesis that, rather than being absolute and static, laws grow:

If all things are continuous, the universe must be undergoing a continuous growth from non-existence to existence. There is no difficulty in conceiving existence as a matter of degree. The reality of things consists in their persistent forcing themselves upon our recognition. If a thing has no such persistence, it is a mere 
dream. Reality, then, is persistence, is regularity. In the original chaos, where there was no regularity, there was no existence. It was all a confused dream. This we may suppose was in the infinitely distant past. But as things are getting more regular, more persistent, they are getting less dreamy and more real. (MS 955) amoeba parallels the evolution put forth in his cosmology; thus, the move from fancy amoeba to fancy worm, and the introduction of finitude and fallibility, counts as evolutionary progress in that it is an instance of the universe's "continuous growth from non-existence to existence." While a First is indeed "full of life and variety," Peirce says, "that variety is only potential; it is not definitely there" (W6: 181). In order for consciousness to truly exist, in a manner that is not epiphenomenal but rather continuous with the rest of reality, it must, like everything else, enter into relations of Secondness and be a persisting thing that forces recognition. This alone will make consciousness part of the reality which corresponds to the final opinion, for "to say that a thing is is to say that in the upshot of intellectual progress it will attain a permanent status in the realm of ideas" (EP2: 2).

has thus given us an account of how consciousness can arise from the unpersonalized mind which underlies all reality. This is not, however, a sufficient account of personhood or the human self. This final evolutionary development requires the introduction of mediation and purposefulness, key elements to the last of the Peircean categories, viz., Thirdness.

\section{Cognition}

fortunately, the extant manuscript ends just as Peirce is prepared to present the upshot of his argument and extend the model to something that might reasonably correspond to the human self (the remainder of the manuscript consists primarily of revised versions of earlier, unrelated, passages). This is typical of many of Peirce's manuscripts. As Josiah Royce noted, Peirce often becomes mired in his own speculation, which may be the reason why he obsessively composed multiple drafts of the same papers which were never completed. Royce complains that "one finds this tendency towards what might be called 'impenetrability' especially evident in his manuscripts. Too often the reader meets with a thought of surpassing brilliancy and follows it eagerly, only to have it disappear like the cuttlefish in an inky blackness of its own secretion" (Royce \& Kernan 1916: 707).

We can, however, make a very reasonable guess as to how this particular story would continue. The progression we see in this passage proceeds according to the model offered by Peirce's categories; this leaves, then, but one category unaccounted for, namely Thirdness. We can thus imagine the "fancy-worm" evolving, by way of the introduction of Thirdness, into something possessing the sort of consciousness required for selfhood.

\section{Physiology and Three Forms of Consciousness}

17 For Peirce, the "activity of nerve-cells is the main physiological requisite for consciousness" (W6: 189). Amoebae, as well as related "slime-moulds" and "protoplasm," do "not differ in any radical way from the contents of a nerve-cell, though [their]

European Journal of Pragmatism and American Philosophy, II-1 | 2010 
functions may be less specialized" (CP 6.133). This is because, while such organisms cannot think, they do "feel," and this sort of feeling is an element of consciousness.

In A Guess at the Riddle, Peirce identifies three abstracted elements of full consciousness: "we have indubitably three radically different elements of consciousness, these and no more. And they are evidently connected with the ideas of one - two - three. Immediate feeling is the consciousness of the first; the polar sense is the consciousness of the second; and synthetical consciousness is the consciousness of a Third or medium" (W6: 186). Here, "feeling" (which he also calls "simple consciousness") and "polar sense" (also called "dual consciousness") are abstractions that are attributed to the proto-consciousnesses of the fancy amoeba and worm, respectively (Peirce calls the third element "synthetical consciousness" or "cognition" and this was likely the subject of the rest of the passage quoted from MS 329). Peirce approaches the third form of consciousness, i.e., "synthetical consciousness," by way of an analysis of the distinctive marks of cognition: "that element of cognition which is neither feeling nor the polar sense [i.e., simple or dual consciousness abstracted from cognition], is the consciousness of a process, and this in the form of the sense of learning, of acquiring, of mental growth is eminently characteristic of cognition [...] This is the consciousness that binds our life together. It is the consciousness of synthesis" (EP1: 260). In identifying cognition (the type of consciousness required for self-hood) with synthesis, Peirce is laying the foundation for his characterization of the self as a Third or sign, the product of an irreducibly triadic relation of mediation.

It is this synthetical consciousness which introduces the possibility of self-consciousness and the growth of the self, for

the highest kind of synthesis is what the mind is compelled to make neither by the inward attractions of the feelings or representations themselves, nor by a transcendental force or haecceity, but in the interest of intelligibility, that is, in the interest of the synthesizing "I think" itself; and this it does by introducing an idea not contained in the data, which gives connections which they would not otherwise have had. (EP1: 261)

Such a consciousness is not restricted to experience the world through sensation of qualities or feelings, as did the fancy amoeba through its solferino color, or by way of determined action to which resistance is sensed, as in the case of the fancy worm. Owing to its mediating capacities, this form of consciousness is able to form plans of action according to purposes (rather than the impelled action of the worm), interpret the general habits observed in the outcomes of such actions, and articulate general ideas to account for these regularities.

21 Cognition, or synthetical consciousness, then, embodies the phenomenological application of Thirdness. It is not only capable of experiencing feeling, and reacting to the impingement of brute reality, but is also equipped with the means by which to unify both action and sensation and relate these back to past experiences as well as project them into the future. This unity is achieved through the adoption of a purpose and is made possible by language and community. The progression from the first to the second stage of the evolution (from "fancy amoeba" to "fancy worm") occurred as a result of the organism becoming implicitly aware of resistance. However, that organism still lacked the capacity to discursively reflect on its own finitude and limitation; as Peirce says, it is aware, merely, of attempting some action and, on occasion, failing in its execution. The 
third stage, however, involves not only this awareness but also a reflective consciousness of itself as being inherently limited.

Peirce will continue the line of speculation he pursues in the incomplete passage drawn from MS 329, eventually developing the phenomenological application of the categories into what he calls three "Universes of Experience." In his late paper "A Neglected Argument for the Reality of God," (1908), he offers the following characterization of these "universes":

of the three Universes of Experience familiar to us all, the first comprises all mere Ideas, those airy nothings to which the mind of poet, pure mathematician, or another might give local habitation and a name within that mind. Their very airynothingness, the fact that their Being consists in mere capability of getting thought, not in anybody's actually thinking them, save their Reality. The second Universe is that of the Brute Actuality of things and facts. I am confident that their Being consists in reactions against Brute forces, notwithstanding objections redoubtable until they are closely and fairly examined. The third Universe comprises everything whose Being consists in active power to establish connections between different objects, especially between objects in different Universes. Such is everything which is essentially a Sign, - not the mere body of the Sign, which is not essentially such, but, so to speak, the Sign's Soul, which has its Being in its power of serving as intermediary between its object and a Mind. Such, too, is a living consciousness, and such the life, the power of growth of a plant. Such is a living institution, - a daily newspaper, a great fortune, a social "movement." (EP 2: 435)

In light of this formulation, we can see that the organisms described in Peirce's evolutionary myth each inhabit one of the three universes of experience: the fancy amoeba belongs to the first, the realm of "mere Ideas"; the fancy worm inhabits the second, "that of Brute Actuality"; and the synthetical consciousness, per hypothesis, occupies the realm of mediation made possible by semiosis. This consciousness is, therefore, itself a sign. Given that Peirce understands the term "sign" in a very general sense (perhaps too general, some have argued), this puts "living consciousness" on the same level as growth in nature (Peirce uses the example of a plant) as well as cultural artifacts such as texts and even larger Intentional structures such as the "spirit of an age" or Peirce's own example of a "social 'movement'." Human consciousness cannot be reduced to its biological features because "synechism recognizes that the carnal consciousness is but a small part of the man. There is, in the second place, the social consciousness, by which a man's spirit is embodied in others, and which continues to live and breathe and have its being very much longer than superficial observers think" (EP2: 3). Peirce thus connects human consciousness with non-human nature as well as with cultural practices and artifacts. This is the heart of his non-reductive naturalism, in its most mature development taking the form of a semiotic model.

The question arises, however, as to what, exactly, makes cognition possible. It is important to note that Peirce understands cognition as both continuous with biological evolution and necessarily embodied, although not reducible to either. In a 1906 attempt at a proof for pragmatism, he says that,

By an experience of active effort is meant what is in the mind (and a less determinate phrase would be used if any were forthcoming) upon the contraction of a voluntary muscle, minus all idea of ulterior purpose, all sensations referred to the muscle that is contracted or to other parts of the body and all that is otherwise plainly no part of the conscious effort. A person may opine that after those subtractions nothing will remain in consciousness; nor will he thereby by any means convict himself of being a bad observer. Nevertheless, such an opinion is 
erroneous. The sense of effort is the sense of an opposing resistance then and there present. It is entirely different from purpose, which is the idea of a possible general regarded as desirable together with a sense of being determined in one's habitual nature (in one's soul, if you like that expression; it is that part of our nature which makes general determinations of conduct) to actualize it. (EP2: 383-4)

What distinguishes cognition, and prevents it from being accounted for purely in terms of biological evolution, is its inherent purposiveness. Peirce characterizes this purposiveness in terms of the self's being able to embody general ideas in actual contexts. In fact, such is the "proper function" of evolved humans: "Animals of all races rise far above the general level of their intelligence in those performances that are their proper function," he says in a later paper, "such as flying and nest-building for ordinary birds; and what is man's proper function if it be not to embody general ideas in art-creations, in utilities, and above all in theoretical cognition?" (EP 2: 443).

A human self is able to perform such a mediating function because it is itself a product of such mediation, in the form of semiosis, i.e., "an action, or influence which is, or involves, a cooperation of three subjects, such as a sign, its object, and its interpretant, this trirelative influence not being in any way resolvable into actions between pairs" (EP 2: 411). Synthetical consciousness is the product of such semiosis and this is what will enable the truly unique characteristics of human selves, their capacity to interpret and produce interactions with an environment with respect to ideal purposes. That is, they are able to act in meaningful ways in the sense Wittgenstein illustrates with his famous question in $\$ 621$ of his Philosophical Investigations. That the self is part of semiosis, i.e., a Sign, is one of Peirce's earliest doctrines, explored in detail already in the "Cognition Series" of papers of $1868-9$.

\section{Childhood Development and Self-Consciousness}

Peirce's story about the evolution of consciousness, which parallels his evolutionary cosmology, is itself paralleled in an account of childhood development which he gives in one of his earliest papers, "Questions Concerning Certain Faculties Claimed for Man." Initially, Peirce says, a child is focused solely on its own body and the sensations it produces. "Only what it touches has any actual and present feeling; only what it faces has any actual color; only what is on its tongue has any actual taste" (W2: 201). This parallels the limited consciousness of the fancy amoeba, i.e., a phenomenological manifestation of Firstness. This focus on the body soon leads the child to discover that changes in environment are often dependent upon contact with that body which is the center of its universe, and its ability to act on things which in turn react to it. This is analogous to the more developed consciousness of the fancy worm and introduces the child to the phenomenological experience of Secondness. The crucial step which follows is the child's acquisition of a language, which Peirce says occurs by way of instinct and imitation. ${ }^{6}$ This parallels the move from fancy worm to a being with cognition, as described above. "It must be about this time," Peirce says, "that he begins to find that what these people about him say is the very best evidence of fact. So much so, that testimony is even a stronger mark of fact than the facts themselves, or rather than what must now be thought of as the appearances themselves. (I may remark, by the way, that this remains so through life; testimony will convince a man that he himself is mad)" (W2: 202). The child soon learns that experience tends to confirm the testimony of others more often than his own beliefs or apprehension of phenomena. 
us, he becomes aware of ignorance, and it is necessary to suppose a self in which this ignorance can inhere. So testimony gives the first dawning of self-consciousness" (W2: 202). This leads Peirce to his famous characterization of the individual self in terms of its fallibility: error "can only be explained by supposing a self which is fallible" which is manifested by its departure from the more reliable judgments of testimony (W2: 203). Consequently, "Ignorance and error are all that distinguish our private selves from the absolute ego of pure apperception" (W2: 203).

We can make better sense of the importance of this claim with a little help from a lecture on Kant's transcendental unity of apperception delivered by Royce. In that lecture, Royce identifies several "characteristic thoughts" of Kant's deduction of the categories. The fourth of these, he claims,

is the thought that we conceive all our experience as unified, as connected, as interrelated, in so far as we view the whole realm of knowable facts as the experience of one virtual self whose time and space forms, whose categories, whose data of knowledge, whose possible experiences, form the topic with which all our sciences are busied [...] The knowable world is the realm of the possible experience of this virtual self to whose one experience we inevitably refer any natural fact. (Royce 1919: 34-35)

Royce emphasizes that this unity remains a virtual self for Kant, and that it is only with later German idealists that it is given a real existence as a sort of social selfhood. According to this Kantian line of thought, something is needed in order to unify all possible experience and thereby grant objectivity to the various subjective experiences of individuals. This virtual self furnishes the conditions for knowledge which enable and determine every individual's possible experience insofar as we all share a common world of phenomena. Peirce's claim, then, is that we are, as individuals, distinguished from this "self" which unifies all possible experience only insofar as we depart from it, in terms of error and ignorance.

This leads Peirce to a characterization of selfhood that places particular emphasis on the community to which it belongs. In a short piece for the journal The Open Court, which was intended as a summary of his synechistic philosophy geared towards a popular audience, he makes this point clear and draws conclusions that may at first appear quite bizarre. The synechist, Peirce says, must never say,

"I am altogether myself, and not at all you." If you embrace synechism, you must abjure this metaphysics of wickedness. In the first place, your neighbors are, in a measure, yourself, and in far greater measure than, without deep studies in psychology, you would believe. Really, the selfhood you like to attribute to yourself is, for the most part, the vulgarest delusion of vanity. In the second place, all men who resemble you and are in analogous circumstances are, in a measure, yourself, though not quite in the same way in which your neighbors are you. (EP2: 2)

For Peirce, then, the self as sign and embodiment of ideas can only exist within a community of other selves (this point is particularly important in Royce's development of Peirce's philosophy). This model is in contrast with a more widespread characterization of the self which owes much to the Cartesian picture Peirce's early papers criticize. Douglas Anderson characterizes such a Cartesian self as "a substantive, isolated individual existing in a web of mechanical causes" and contrasts it with "Peirce's realistic, synechistic, and semiotic conception of the self" (Anderson 2006: 163). The Cartesian model understands the self primarily in terms of its agency and atomicity and understands words and other signs as externalized expressions of subjective intention;

European Journal of Pragmatism and American Philosophy, II-1 | 2010 
they have meaning insofar as some agent or agents impart meaning to them. The prevalence of this account of the self is clear in twentieth century analytic philosophy of art, especially arguments surrounding interpretation. A common assumption in such discussions is that artifacts are meaningful structures only insofar as a creative agent can be credited with their production. Thus, a "wave poem" - i.e., what appear to be words written in the sand by the movement of waves - only counts as a poem if it were produced by an agent who intended to write a poem. ${ }^{7}$ For Peirce, such a model of is merely another instance of the nominalism he opposes throughout his career. To say that signs are only meaningful insofar as we grant them meaning is to make them mere names, and thus discount the reality of generals. What's more, it gets the order of evolution backwards. For Peirce, semiosis precedes selfhood - selves are but parts of that process which comprises the mind underlying all of reality. This is the crux of Peirce's naturalism; "all communication from mind to mind is through continuity of being," he says (EP 2:3), and "all mind is directly or indirectly connected with all matter, and acts in a more or less regular way" (CP 6.268).

Thus, the fallibilist characterization of the self as the locus of error and ignorance, which at first appears to be merely negative, reveals itself to be an important and positive model in at least three ways: first, it motivates inquiry, experimentation and the embodiment of ideas. It does this by introducing and universal sort of doubt and "existential" crisis with respect to truth and inquiry. Peirce places truth at the end of infinite inquiry; as such, it is beyond the grasp of any individual or community within finite time. Given that we can never know whether or not any given belief or accepted fact forms part of the final opinion, we must view all human inquiry as inherently fallible, admitting that any belief or body of accepted knowledge could be wrong, even radically so. If truth as a concept is defined in such a way that it can never be practically attained by any finite inquirer, then a sort of universal irritation of doubt is introduced. Thus, the actual, finite inquirer is always confronted with an objective uncertainty, or "anxiety," if you will, regarding his or her attempts at reaching a true account. As David Savan argues, in the absence of such doubt, reason itself ceases to exist:

The perfect and complete knowledge of the ideal community would be the death of reason. What such an ideally knowledgeable community affirmed would necessarily exist, and what it denied would necessarily not be. The distinction between truth and falsehood, reality and illusion, would disappear [...] A world entirely without a spark of chance-spontaneity would be crystalline, perfectly rigid, and perfectly dead. (Savan 1965: 49)

Second, understanding the self as a locus of error and ignorance is necessary in order for reasons to have the normative force they do. Initiation into language, and the accompanying realization that testimony is a greater authority even than personal experience, is initiation into something bigger than the self, a world that can rightfully make demands and offer justifications (rather than mere exculpations). ${ }^{8}$ Finally, a model of selfhood based on the idea of fallibilism, which itself becomes the doctrine of synechism when "objectified," bridges the gap between this world of reasons and justifications and the material world (CP 1.171). In Peirce's words, "viewing a thing from the outside, considering its relations of action and reaction with other things, it appears as matter. Viewing it from the inside, looking at its immediate character as feeling, it appears as consciousness" (CP 6.268). 


\section{Personality}

Peirce's guess at the sphynx's riddle about "the meaning of man," is, in its simplest form, semiosis. In our own experience (and thus the only known manifestation of such cognition) this takes the form of language. In an unpublished manuscript, Peirce says

By a 'person,' by the way, I suppose we mean an animal that has command of some syn- tactical language, since we neither call any of the lower animals persons, (for, though they be able to convey their meanings by various sounds, they do not combine different sounds so as to build sentences,) nor do we call an infant that cannot yet put two words together to make a sentence. One might almost define a person as an animal possessed of moral self-control; but that would not be correct unless we were prepared to call some dogs, horses, parrots, hens, and other creatures persons, which I take it nobody does, in spite of the moral respect to which they are often well-entitled. One feels that there is an injustice in our nonexpression of respect for them. Yet, after all, the word person, $\mathrm{p}|\mathrm{e}| \mathrm{r}|\mathrm{s}| \mathrm{o}|\mathrm{n}| \mathrm{a}$, has explicit reference to speech. (MS 659, as cited in Lane 2009: 20)

Robert Lane has recently offered a Peircean-inspired account of selves that draws heavily on this passage. For Lane, "a person is an animal whose nervous system functions in a specific way, viz. to engage in a continuous process of sign-interpretation" (Lane 2009: 8). Lane makes it clear that he does not intend for this to be a definition of personhood, but only a partial and rough characterization of it; something more is needed to account for the sui generis nature of human personhood. This is evident when we look to organisms like bees, a case that Peirce himself famously treats.

Honeybees are, as is well-known, capable of a form of communication, what is often referred to as "dancing," which fits Peirce's description of semiosis: the significant movements of an individual bee (a sign) represent the location, distance and nature of a pollen, nectar or water source (an object) than can be interpreted by other bees who will follow that direction to the target (an interpretant). Consequently, honeybees are animals whose nervous systems function in such a ways as to enable them to engage signproduction and interpretation, as in Lane's characterization of a person. However, honeybees are not taken to be persons in the same sense as when we ascribe the term to human selves. Part of Lane's motivation for focusing on the animal embodiment of human persons is that he takes this to be the essential factor in the individuation of selves. "Persons are individuated from each other by being individual animals, just as different copies of Nader's Unsafe at Any Speed are individuated from each other by being different bound volumes" (Lane 2009: 11). The honeybee example highlights the extent to which this account of individuality must be augmented, for, while each bee is an "individual animal" which engages in sign-making and interpretation, it is not an "individual" in the sense of the term as applied to human persons, a sense that goes beyond numerical differentiation. In fact, what is most intriguing about the honeybees in this context is that they display none of the characteristics of individuality that figure prominently in our intuitions about and treatments of human persons; so much so that we are often led to speak of a "hive mind" of which each bee is merely a part and thus displays very little in the way of an individual mind (a potentially essential characteristic of personhood). We see, then, that not only is something more needed to distinguish human cognition from incipient forms of consciousness in the animal world, but also to

European Journal of Pragmatism and American Philosophy, II-1 | 2010 
distinguish human persons as individuals (in the strong sense captured in ethical discourse) from their fellows.

Peirce is concerned with this element of selfhood from the very beginning of his career, and addresses it in the 1866 Lowell lecture which emphasizes the similarities between people and words.

Each man has his own peculiar character. It enters into all he does. It is in his consciousness and not a mere mechanical trick, and therefore it is by the principles of the last lecture a cognition; but as it enters into all his cognition, it is a cognition of things in general. It is therefore the man's philosophy, his way of regarding things; not a philosophy of the head alone - but one which pervades the whole man. This idiosyncrasy is the idea of the man; and if this idea is true he lives forever; if false, his individual soul has but a contingent existence. (CP 7.595)

This passage prefigures much of what Peirce will later say about the self, including the "immortality" he is willing to attribute to persons as well as his theory of truth as the final opinion. The "peculiar character" he describes is the positive element of his model of the self, what he elsewhere refers to as "personality."

According to Peirce, "personality is some kind of coördination or connection of ideas" (EP1: 331). Not just any arrangement of "conceptions working together" produces a personality; the parts of this species of mind must be "coordinated in a particular way." Moreover, "the word coordination [...] implies a teleological harmony of ideas, and in the case of personality this teleology is more than a mere purposive pursuit of a predeterminate end; it is a developmental teleology. This is personal character. A general idea, living and conscious now, it is already determinative of acts in the future to an extent to which it is not now conscious" (EP1: 331). Peirce's invocation of teleology here is telling. Teleology, for Peirce, is always connected with the idea of the infinite, and the goal of any such development is never available to actual inquirers in finite time. It is not epiphenomenal; we do carry with us the "freightage of eternity" (EP 2: 449), but we can never know it or even know that we are actually approaching closer toward it at any given moment. ${ }^{9}$ For this reason, "personality, like any general idea, is not a thing to be apprehended in an instant. It has to be lived in time; nor can any finite time embrace it in all its fullness" (EP 1:331).

41 Moreover, this "living in time" of personality reveals the reciprocal evolution of human selves and the general ideas they embody.

Something of the general nature of personality there is in all general ideas. These conceptions are in a certain sense creations of the human intelligence, but in another aspect the human mind is the creation of these conceptions working together. These general conceptions are no figments, they are real things - more than that, they are living beings with something like life and something like personality. Mind acts upon mind by virtue of its continuity; and this continuity involves generality. (MS 954)

The reality of generals or ideas in this context comes down to the recognition that, while such culturally significant structures are indeed constructions, they are essential to the emergence of persons, contributing to our existence as selves equally as much as the forces of biology and physics fashion our embodied existence. The importance of Peirce's synthesized metaphysics is in drawing attention to the fact that a full account of personhood is impossible without attending to both aspects of the development of the self, i.e., the biological and the culturally significant. This is by no means an entirely novel conception; the insight might be traced back to the sophists of fifth-century Athens 
who, as Sarah Broadie puts it, came to the "dual realization" of "our power of logos [which variously means 'speech,' 'language,' 'argument,' 'reason'] and its power over us" (Broadie 2003: 75)..$^{10}$

The conclusion this leads us to is that human persons or selves are artifacts of cultural, brought about by the semiosis of language but in a way that is continuous with the evolution of the "natural" world. This "natural artifactuality" is the alternative to the natural-artificial distinction which has dominated most discussions of the self. ${ }^{11}$

To understand Peirce's account of actual human selves, then, requires analysis of two concepts that, despite their close affinity to mind and consciousness, Peirce keeps somewhat distinct. The first is self-consciousness and the second, personality. Bringing all three (Mind, self-consciousness and personality) together gives us a reasonable account of Peirce's model of the self; however, the third element, personality, remains largely unexplained within Peirce's own work. In order to better understand its nature and function requires, I argue, a turn to Royce's development of this and related Peircean concepts. Such an analysis extends, of course, well beyond the scope of this paper, but is assuredly a fruitful one.

\section{BIBLIOGRAPHY}

ANDERSON D., (2006), "Peirce and Cartesian Rationalism," in Shook J. \& Margolis J. (eds.), A Companion to Pragmatism, Boston, Blackwell.

BERNSTEIN R., (1971), Praxis and Action: Contemporary Philosophies of Human Activity, Philadelphia, University of Pennsylvania Press.

BROADIE S., (2003), "The Sophists and Socrates," in Sedley D. (ed.), The Cambridge Companion to Greek and Roman Philosophy, Cambridge, Cambridge University Press.

GRENE M., (1974), The Understanding of Nature: Essays in the Philosophy of Biology, Dordrecht, D. Reidel.

ISENMINGER G. (ed.), (1992), Intention and Interpretation, Philadelphia, Temple University Press. LANE R., (2009), “Persons, Signs, Animals: A Peircean Account of Personhood," Transactions of the Charles S. Peirce Society, 45 (1), 1-26.

MARGOLIS J., (2009), The Arts and the Definition of the Human, Stanford, Stanford University Press. MCDOWELL, (1996), Mind and World, Cambridge, MA, Harvard University Press.

OPPENhEIM F., (1993), Royce's Mature Ethics, Notre Dame, Indiana Notre Dame University Press. PEIRCE C.S., (1931-58), Collected Papers of Charles Sanders Peirce, 8 vols, Hartshorne C. et al. (eds)., Cambridge, MA, Harvard University Press. References are given as " $\mathrm{CP}$ " followed by volume number and section number (for example CP 8.265). 
PEIRCE C.S., (1975-87), Charles Sanders Peirce: Contributions to the Nation, Ketner K. and Cook J., eds., Lubbock, Texas Tech University Press. References are given as "N" followed by volume number and page number (for example N 1: 201).

PEIRCE C.S., (1992-98), The Essential Peirce, 2 vols., Houser N. et al. (eds.), Indianapolis, Indiana University Press. References are given as EP followed by volume number and page number (for example EP 2: 2).

PEIRCE C.S., (1982-2000), Writings of Charles S. Peirce: A Chronological Edition, Vols 1-8, Fisch M. et al. (eds.), Indianapolis Indiana University Press. References are given as "W" followed by volume number and page number (for example W 2: 241).

PEIRCE C.S., Unpublished Manuscripts, The Charles S. Peirce Papers, Cambridge, MA, Houghton Library, Harvard University.

ROBIN R., (1967), Annotated Catalogue of the Papers of Charles S. Peirce, Amherst, MA, University of Massachusetts Press.

ROYCE J., (1919), Lectures on Modern Idealism, New Haven, Yale University Press.

ROYCE J. \& F. KERNAN, (1916), “Charles Sanders Peirce,” The Journal of Philosophy, Psychology and Scientific Methods, 13 (26) (Dec. 21, 1916), 701-9.

SAVAN D., (1965), "Decision and Knowledge in Peirce," Transactions of the Peirce Society, 1 (2), 35-51.

\section{NOTES}

1. The brackets enclose a note added by Peirce in the margin of the letter.

2. I draw the term "Darwinianized Hegelism" from one of Peirce's own works, a review of David G. Ritchie's book, Darwin and Hegel with Other Philosophical Studies, written for The Nation. At the end of the review, Peirce speculates about a promising direction for philosophy that draws on his fallibilist theory of truth and inquiry and which captures intuitions put forth by both Darwin and Hegel (as Peirce understood each). Here is the passage in question: An a-priori philosophy ought not to pronounce in advance upon the truth of anything which is capable of verification or refutation by subsequent experience. But beyond the realm of verification truth and falsity lose their meanings. Hence the moment a philosopher, upon a-priori or epistemological grounds, enunciates any proposition whatever as true, we are warned to be upon our guard against some jugglery. Where we have no scientifically observed facts to go upon, the prudent thing is to confess our downright ignorance. Even where we have such facts, we are subject to a probable error. From this pregnant fact, if one only takes it to heart, can be developed a whole Darwinianized Hegelism, having fruitful suggestions and indications for the prosecution of science and for the conduct of life (Peirce 1975-87: 201-2).

3. Cf. W 6: 180 .

4. References to Peirce's unpublished manuscripts follow (Robin 1967).

5. It is also interesting to note that, when reference to a specific color is required by the discussion, Peirce almost invariably chooses a shade of red. I am reluctant to speculate at this point as to whether this indicates anything other than personal preference, but given that Peirce does favor the color so greatly in his writing, it is perhaps a line of inquiry worth pursuing.

6. Cf. EP 2: 443.

7. For detailed discussions of these, and related issues, see Isenminger 1992.

8. For a useful account of the difference, from a different perspective, see McDowell 1996.

9. Cf. CP 1.141 .

European Journal of Pragmatism and American Philosophy, II-1 | 2010 
10. The material enclosed in square brackets is Broadie's own gloss of the Greek term "logos."

11. The term "natural artifact" is borrowed from the work of Joseph Margolis and Marjorie Grene. See, especially, (Margolis 2009: 26-7) and (Grene 1974: 358). 